\title{
KETERAMPILAN BERPIKIR KREATIF SISWA DALAM MENYELESAIKAN SOAL OLIMPIADE MATEMATIKA BERDASARKAN LEVEL METAKOGNISI
}

\author{
Mohammad Tohir \\ Universitas Ibrahimy, Situbondo, Indonesia \\ matematohir@ibrahimy.ac.id
}

\begin{abstract}
:
The research aims to describe the level of creative thinking ability of students in solving mathematics olympiad problems based on students' metacognition levels by using the qualitative descriptive approach. The subjects of this study were the students at State of Junior High School (SMPN) 2 Jember involving the learning of Olympiad mathematics. The data collection was carried out based on the student's creative thinking ability test sheets, interviews, and observations. Test questions given to the students were mathematics olympiad questions. The analysis of the Miles and Huberman models were used for data analysis. The results exhibited that the level of creative thinking skills of the students in solving mathematics Olympiad questions were 29.41\% (less creative), $41.18 \%$ (quite creative), $11.76 \%$ (creative) and $17.65 \%$ (very creative). On the other hand, the metacognitive level of SMPN 2 Jember students were $64.71 \%$ at level 2 (aware use), $23.53 \%$ at level 3 (strategic use) and $11.76 \%$ at level 4 (reflective use). In addition, the literatures indicate that there are several factors affectting the creative thinking skills and metacognition level, among them is an understanding of the information of the problem, compiling an appropriate strategies, skills of the chosen strategy, skills of answer elaboration, mastery of the Mathematics Olympiad material and a tendency to rely on the memorization or imitations based on previous or discussed solutions.
\end{abstract}

Keywords: creative thinking, skills, mathematics Olympiad, metacognition.

\section{PENDAHULUAN}

Setiap tahun ajaran di Sekolah Menengah Pertama Negeri (SMPN) 2 Jember selalu mengadakan tes kemampuan awal dalam bentuk soal pilihan ganda tentang pengetahuan materi olimpiade kepada seluruh siswa baru untuk bidang studi Matematika, Ilmu Pengetahuan Alam (IPA) dan Ilmu Pengetahuan Sosial (IPS). Khususnya bidang studi matematika masih dilakukan pre-test baik kepada siswa baru yang sudah dinyatakan lolos maupun siswa kelas VIII. Hal ini dilakukan untuk mengetahui kemampuan masing-masing individu dengan soal tes yang berbentuk soal uraian. Hasil pekerjaan siswa kemudian dianalisis untuk dievaluasi dan mengambil langkah dalam model pembinaan yang dilakukan oleh tim pembinan olimpiade matematika. Para pembinan telah menyepakati model pembinaan yang akan digunakan adalah model pembinaan diskusi secara kelompok kecil, pembinaan secara terbimbing, metode ilmiah (Scientific) dengan pembelajaran DL (Discovery Learning) dan model pembinaan dengan menggunakan buku olimpiade matematika yang disusun oleh tim pembina. Sehingga diharapkan melalui pembinaan olimpade matematika ini, siswa dapat memiliki kemampuan berpikir logis, analitis, sistematis, kritis, dan kreatif, serta memiliki kemampuan bekerja

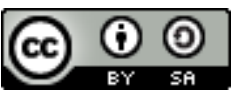

Content from this work may be used under the terms of the Creative Commons AttributionShareAlike 4.0 International License that allows others to share the work with an acknowledgment of the work's authorship and initial publication in this journal. 
sama yang baik. Sehingga mampu dalam membantu untuk mewujudkan keterampilan abad 21 (P21, 2014), yaitu pembelajaran yang menuntut siswa untuk memiliki kompetensi dalam berpikir kritis, berpikir kreatif, komunikatif, dan kolaboratif.

Menurut Munandar (2012) mengemukakan bahwa berpikir kreatif dapat dirumuskan sebagai kemampuan yang mencerminkan aspek-aspek kelancaran (fluency), keluwesan (flexibility), dan orisinalitas dalam berpikir(originality), serta kemampuan untuk mengembangkan, memperkaya atau memperinci suatu gagasan (elaboration). Menurut Siswono (2008) dalam berpikir kreatif, seseorang akan melalui tahapan mensintesis ide-ide, membangun ide-ide, merencanakan penerapan ide-ide, dan menerapkan ide tersebut sehingga menghasilkan sesuatu atau produk yang baru. Produk yang dimaksud adalah kreativitas. Berpikir tentang apa yang dipikirkan dalam hal ini berkaitan dengan kesadaran siswa terhadap kemampuannya untuk mengembangkan berbagai cara yang mungkin ditempuh dalam memecahkan masalah, atau yang disebut dengan metakognisi. Keterampilan kemampuan berpikir kreatif memiliki ciri-ciri tertentu dan dapat dijadikan dasar penelitian kualitatif yang sifatnya analisis deskriptif. Menurut Tohir (2017) mengatakan bahwa masalah matematika adalah suatu masalah yang membutuhkan teknik tertentu untuk memecahkannya baik berupa soal rutin maupun non rutin. Kemampuan berpikir dalam mengidentifikasi dan membangun rumus dalam matematika diperlukan untuk menumbuhkan pemahaman siswa pada materi dan menghasilkan pembelajaran yangbermakna (Tohir, Abidin, Dafik, \& Hobri, 2018; As'ari, Tohir, Valentino, Imron, \& Taufiq, 2017).

Metakognisi memiliki peranan penting dalam mengatur dan mengontrol proses kognitif seseorang dalam belajar dan berpikir. Menurut Gartmann \& Freiberg, (1995), dalam pemecahan masalah terdapat proses menyadari dan mengatur berpikir tentang bagaimana siswa membuat pendekatan terhadap masalah, memilih strategi yang digunakan untuk menemukan pemecahan dan bertanya kepada diri sendiri tentang masalah tersebut. Keterampilan metakognisi juga berpengaruh pada kecerdasan siswa dan pengembangan proses berpikir kreatif siswa tersebut (Romli, 2012). Lebih rinci Syaiful (2011) mengungkapkan bahwa metakognisi dibagi menjadi dua komponen yaitu pengetahuan metakognisi dan ketrampilan metakognisi. Sedangkan menurut Kathwohl (Romli, 2012) Pengetahuan metakognisi adalah pengetahuan tentang kognisi secara umum sama dengan kesadaran dan pengetahuan tentang kognisi-diri seseorang, sedangkan ketrampilan metakognisi tentang kesadaran seseorang untuk melakukan perencanaan, mengikuti perkembangan, dan memantau proses belajarnya.

Keterampilan metakognisi memiliki indikator yang mengacu pada gambaran aktivitas-aktivitas siswa pada setiap komponen metakognisi dari Romli (2012). Berikut adalah Tabel 1 tentang indikator keterampilan metakognisi. 
Tabel 1 Indikator Keterampilan Metakognisi

\begin{tabular}{ll}
\hline $\begin{array}{c}\text { Keterampilan } \\
\text { Metakognisi }\end{array}$ & \multicolumn{1}{c}{ Indikator } \\
\hline Perencanaan & 1. Siswa dapat menentukan pengetahuan awal apa yang \\
digunakan untuk membantu menyelesaikan masalah \\
matematika
\end{tabular}

Hasil penelitian yang dilakukan oleh Sari, Ikhsan, \& Saminan (2017) menunjukkan bahwa ada perbedaan yang signifikan antara siswa kelompok tinggi, sedang, dan rendah dalam proses berpikir kreatif siswa dalam memecahkan masalah matematika berdasarkan model Wallas. Hasil penelitian yang dilakukan oleh Rahmawati (2016) menunjukkan bahwa melalui pembelajaran SSCS berbantuan Quipper School kemampuan berpikir kreatif siswa dipengaruhi oleh kesadaran metakognisinya. Adapun hasil penelitian yang dilakukan oleh Tohir, Susanto, Hobri, Suharto, \& Dafik, (2018) menunjukkan bahwa pemahaman siswa terhadap semua materi olimpiade matematika masih sangat kurang dan perlu diadakan pembinaan yang intensip secara kontinu dengan menggunakan berbagai model pembinaan. Pemecahan masalah model Polya sangat cocok untuk soal jenis masalah rutin, sedangkan pemecahan model Krulik-Rudnick lebih cocok untuk masalah yang jenisnya tidak rutin. Sedangkan hasil penelitian yang dilakukan oleh

Alifmatika: Jurnal Pendidikan dan Pembelajaran Matematika, Desember 2019, Vol. 1, No. 1 
Kholid M. N.; \& Lestari (2019) menunjukkan bahwa siswa dengan kemampuan matematika tinggi memiliki metakognisi terbaik. Sedangkan siswa dengan kemampuan matematika sedang dan rendah hanya memenuhi dibawah level 5 sub-indikator pengetahuan metakognisi dan dibawah level 3 sub-indikator keterampilan metakognisi.

Berdasarkan uraian diatas, maka perlu diadakan suatu penelitian kepada siswa yang mengikuti pembinaan olimpiade matematika apabila ditinjau dari level metakognisi terhadap tingkat keterampilan berpikir kreatif mereka. Sehingga dengan mengetahui tingkat keterampilan berpikir dan level metakognisi siswa, maka akan menjadi acuan dalam melaksanakan perbaikan pembinaan guna peningkatan tingkat penguasaan siswa, khususnya pembinaan olimpiade matematika. Oleh karena itu, maka tujuan penelitian yang dilakukan oleh penulis adalah untuk mendeskripsikan keterampilan berpikir kreatif siswa dalam memecahkan berbagai macam bentuk soal olimpiade matematika berdasarkan level metakognisinya.

\section{METODE PENELITIAN}

Metode penelitian merupakan penelitian kualitatif. Penelitian kualitatif memiliki ciri-ciri yaitu mempunyai latar belakang alamiah (konteks dari suatu keutuhan), manusia sebagai alat atau instrumen, menggunakan metode kualitatif, analisis data secara induktif, penyusunan teori berdasarkan data, data bersifat deskriptif, lebih mementingkan proses daripada hasil, adanya batas yang ditentukan oleh fokus, adanya kriteria khusus untuk keabsahan data, desain bersifat sementara, dan hasil penelitian merupakan hasil keputusan bersama (Tohir et al., 2018).

Subjek penelitian yang dilakukan oleh penulis adalah siswa SMPN 2 Jember dengan jumlah siswa yang mengikuti pembinaan olimpiade matematika sebanyak 17 orang. Sehingga diharapkan dapat memberi gambaran yang menyeluruh dari tingkat keterampilan berpikir kreatif siswa.

Teknik pengumpulan data merupakan langkah yang paling utama dalam penelitian, karena tujuan utama dari penelitian adalah mendapatkan data, yang selanjutnya akan dianalisis untuk menjawab permasalahan yang diajukan. Data dan sumber data yang digunakan dalam penelitian ini adalah data hasil test soalsoal olimpiade, data wawancara, dan observasi. Data yang telah diperoleh akan direduksi, disajikan, disimpulkan dan diverifikasi. Verifikasi data dilakukan dengan triangulasi, pengecekan teman sejawat dan ketekunan pengamatan.

Analisis data yang pertama didapat dari hasil test yang diberikan kepada siswa yang mengikuti pembinaan olimpiade matematika untuk mengukur keterampilan berpikir kreatifnya. Klasifikasi berpikir kreatif berdasarkan indikator tingkat berpikir kreatif dikategorikan ke dalam 5 kategori yaitu sangat kreatif, kreatif, cukup kreatif, kurang kreatif, dan tidak kreatif. Menurut Siswono (2008) pembagian tingkatan tersebut berguna untuk memprediksi kemampuan siswa dalam berpikir kreatif, khususnya dalam bidang matematika. Rumusan tentang keterampilan berpikir kreatif siswa ditunjukkan dalam tabel 2 berikut. 
Tabel 2 Indikator Tingkat Keterampilan Berpikir Kreatif

\begin{tabular}{ll}
\hline \multicolumn{1}{c}{ Tingkat } & \multicolumn{1}{c}{ Indikator Tingkat Keterampilan Berpikir Kreatif } \\
\hline $\begin{array}{l}\text { Tingkat 4 } \\
\text { (Sangat Kreatif) }\end{array}$ & $\begin{array}{l}\text { Siswa sangat terampil dalam menemukan startegi yang } \\
\text { dipilih dan menyelesaikan soal-soal olimpiade matematika } \\
\text { dengan tepat dan benar }\end{array}$ \\
Tingkat 3 & $\begin{array}{l}\text { Siswa terampil dalam menemukan startegi yang dipilih dan } \\
\text { menyelesaikan soal-soal olimpiade matematika dengan tepat } \\
\text { dan benar }\end{array}$ \\
Tingkat 2 & $\begin{array}{l}\text { Siswa cukup terampil dalam menemukan startegi yang dipilih } \\
\text { dan menyelesaikan soal-soal olimpiade matematika dengan }\end{array}$ \\
tepat dan benar
\end{tabular}

Sedangkan analisis data yang kedua, didapat dari tingkat kesadaran seseorang dalam proses berpikir menurut Swartz dan Perkins (Sophianingtyas \& Sugiarto, 2013) meliputi:

1) Level 1: tacit use, merupakan jenis berpikir dalam membuat keputusan tanpa berpikir tentang keputusan tersebut. Siswa hanya mencoba atau asal menjawab dalam memecahkan soal.

2) Level 2: aware use, merupakan jenis berpikir yang menunjukkan seseorang menyadari "apa" dan "kapan" dia melakukan sesuatu. Siswa menyadari segala sesuatu yang dilakukan dalam memecahkan masalah.

3) Level 3: strategic use, merupakan jenis berpikir yang menunjukkan seseorang mengorganisasi pemikirannya dengan menyadari strategi-strategi khusus yang meningkatkan ketepatan berpikir. Siswa mampu menggunakan dan menyadari strategi yang tepat dalam memecahkan masalah.

4) Level 4: reflective use, merupakan jenis berpikir yang menunjukkan seseorang melakukan refleksi tentang pemikirannya dengan mempertimbangkan perolehan dan bagaimana memperbaikinya. Siswa mampu menyadari atau memperbaiki kesalahan yang dilakukan.

Penyajian data (data display) pada penelitian kualitatif bisa dilakukan dalam bentuk uraian singkat, bagan, hubungan antar kategori, flowchart dan sejenisnya. Miles dan Huberman sebagaimana dikutip oleh Sugiyono (2017) mengatakan bahwa "the most frequent form of display data for qualitative research data in the past has been narrative text". Bentuk penyajian data yang paling sering digunakan dalam penelitian kualitatif adalah teks naratif. Penyajian data meliputi pengklasifikasian dan identifikasi data, menuliskan kumpulan data yang terorganisir dan terkategori sehingga dapat ditarik kesimpulan. 


\section{HASIL DAN PEMBAHASAN}

Pelaksanaan pembinaan olimpiade matematika yang diberikan kepada siswa merupakan suatu rentetan proses pemahaman konsep-konsep dasar matematika secara hirarki. Apabila dalam pelaksanaan pembinaan olimpiade sebelumnya mengalami gangguan atau tidak dapat menyerap materi dengan baik, maka akan terjadi gangguan atau kebuntuan dalam mempelajari konsep yang lebih tinggi. Soal-soal test yang diberikan kepada siswa merupakan soal-soal olimpiade matematika yang sangat familiar bagi siswa dan seharusnya sudah menjadi konsep sederhana bagi siswa yang mengikuti pembinaan olimpiade matematika. Dari hasil test yang telah dilakukan oleh peneliti, terdapat data-data tentang kesulitankesulitan siswa dalam menyelesaikan soal test, berikut contoh hasil test yang diberikan kepada siswa yang mengikuti pembinaan olimpiade matematika di SMPN 2 Jember yang kemudian dianalisis oleh peneliti.

\section{Temuan pada alternatif penyelesaian soal test yang unik}

\section{Pada Soal Nomor 2:}

Saat ini umur Rohim dan umur Ridwan kurang dari 100 tahun. Jika umur Rohim dan umur Ridwan ditulis secara berurutan, maka diperoleh suatu bilangan empat digit (angka) yang merupakan kuadrat sempurna. Dua puluh tiga tahun kemudian, jika umur mereka ditulis dengan cara yang sama, maka diperoleh bilangan empat digit lain yang juga merupakan kuadrat sempurna. Jika umur mereka diasumsikan merupakan bilangan bulat positif, berapakah umur mereka saat ini?

\section{Alternatif penyelesaian siswa $A$}
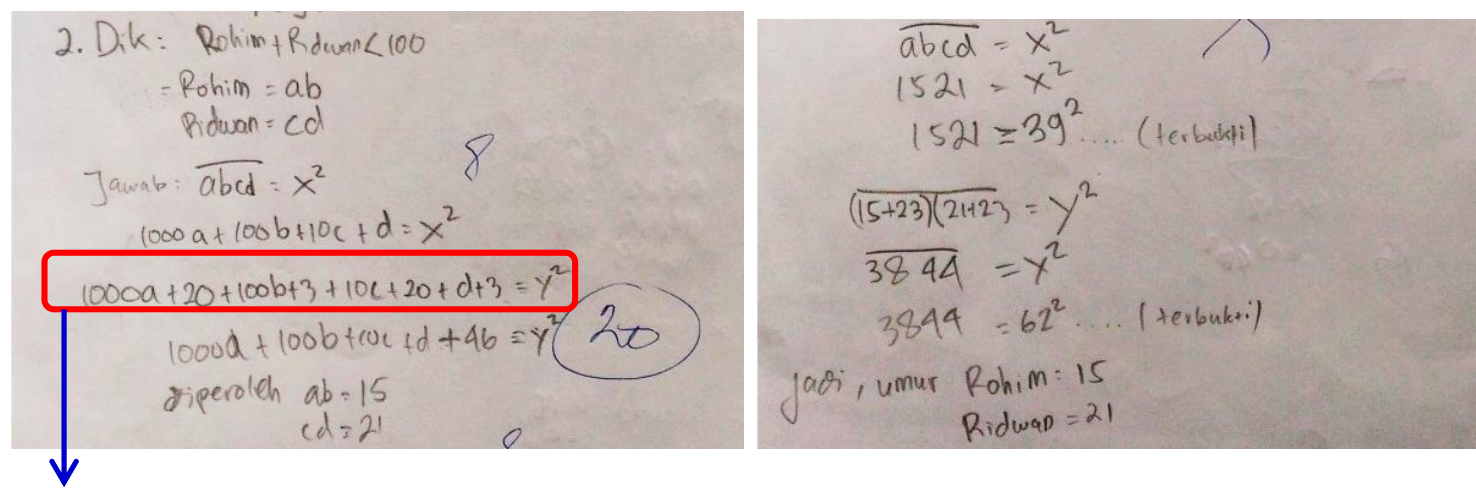

Strategi yang digunakan oleh siswa $A$ sangat kreatif dan berbeda dengan strategi dari siswa yang lain, yaitu untuk menemukan umur Rohim dan Ridwan, Siswa A sagat mahir dam mememilih dan menggunakan strategi yang dipilih, yaitu menggunakan strategi manipulasi aljabar. Siswa $A$ tidak lupa untuk mengecek hasil yang diperoleh. Sehingga siswa $A$ sudah melakukan refleksi tentang pemikirannya dengan mempertimbangkan perolehan dan bagaimana memperbaikinya. Oleh karena alternatif penyelesaiannya dari siswa $A$ sangat kreatif, maka penulis melakukan wawancara khusus kepada siswa $A$, bagaimana dia menemukan strategi dan menggunakannya. Berikut hasil wawancaranya. 
Peneliti : apakah kamu pernah tahu soal seperti ini?

Siswa $A$ : saya sudah pernah tau soal seperti ini dan caranya saya masih ingat, bagaimana menyelesaikan soal seperti ini.

Peneliti : bagaimana strategi yang kamu pilih untuk mendapatkan jawaban dari soal tersebut?

Siswa $A$ : caranya, dengan menggunakan manipulasi aljabar yang pernah saya pelajari sebelumnya dengan memperhatikan bahwa abcd merupakan kuadrat sempurna.

Peneliti : ouh begitu, terus.. bagaimana caranya kamu memperoleh nilai $a b=15$ dan $c d=21$

Siswa $A$ : diketahui $a b c d=$ kuadrat sempurna,

Kemudian saya nalarkan bahwa bilangan kuadrat sempurna yang terdiri dari 4 digit dapat dimulai dari 32 sampai 99, selanjutnya saya menguji kuadrat sempura tersbut sehingga diperoleh kuadrat sempurna 1521, jadi $a b=15$ dan $c d=21$. Selanjutnya saya buktikan seperti yang di lembar jawaban.

Berdasarkan hasil wawancara tersebut menunjukkan bahwa siswa $A$ memiliki kemampuan berpikir kraetif pada kategori tinggi dan berada pada level 4 berdasarkan level metakognisinya, karena proses berpikirnya dalam memahami soal dengan menggunakan strategi unik dan dalam proses penyelesaiannya sangat cermat. Menurut hasil penelitian Wulantina (2015) menyimpulkan bahwa siswa dengan kemampuan tinggi pada tahap persiapan siswa mengidentifikasi masalah yang ditanyakan dengan baik, siswa memilih informasi yang dibutuhkan dan informasi yang tidak dibutuhkan dalam penyelesaian masalah dengan tepat. Menurut Duning (Coutinho, 2007) menyatakan metakognisi merupakan prediktor yang kuat dalam prestasi akademik. Siswa dengan tingkat metakognisi baik/tinggi akan memperlihatkan prestasi akademik yang lebih baik dibandingkan siswa dengan tingkat metakognisi yang tidak baik/rendah.

\section{Pada Soal Nomor 4:}

Rudi berangkat ke sekolah pukul 6.00 setiap pagi. Bila bermobil dengan kecepatan $40 \mathrm{~km} / \mathrm{jam}$, dia tiba di sekolah terlambat 20 menit. Bila kecepatan $60 \mathrm{~km} / \mathrm{jam}$, dia tiba 15 menit lebih awal. Tentukan pukul berapakah jam pertama dimulai di sekolah Rudi. 


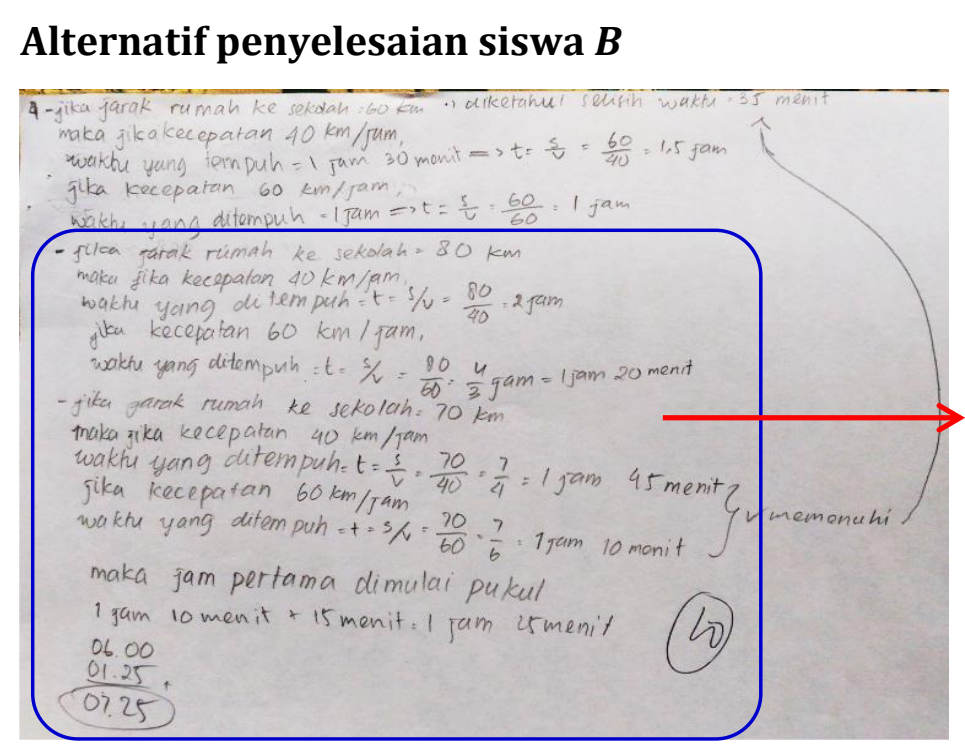

Strategi yang digunakan oleh siswa $B$ cukup unik dan berbeda dengan strategi dari siswa yang lain, yaitu untuk menemukan jam pertama masuk di sekolahan Rudi dengan memisalkan jarak rumah ke skolah jika sejauh 80 $\mathrm{km}$ dan $70 \mathrm{~km}$. Kemudian mengeceknya pada masing kecepatan yang digunakan berdasarkan waktu yang telah diketahui.

Kemudian siswa $B$ tidak lupa untuk mengeceknya dengan selisih waktu yang didapat jika menggunakan kecepatan yang berbeda. Strategi yang digunakan oleh siswa B cukup membantu dalam mendapatkan jawaban dari soal, akan tetapi ia lupa bahwa sebenarnya jarak rumah Rudi ke sekolah memiliki jarak yang tetap. Dikarenakan memiliki jarak tetap, maka perbandingan waktu dan perbadingan kecepatannya adalah sama, sehingga permasalahan ini termasuk perbandingan senilai. Oleh karena alternatif penyelesaiannya dari siswa $B$ cukup unik, maka penulis melakukan wawancara khusus kepada siswa $B$, bagaimana dia menemukan strategi dan menggunakannya. Berikut hasil wawancaranya.

Peneliti : apakah kamu pernah tahu soal seperti ini?

Siswa $B$ : saya pernah lihat soal seperti ini, tapi lupa caranya, tapi say mendoba menggunakan logika nalar saya.

Peneliti : bagaimana strategi yang kamu pilih untuk mendapatkan jawaban dari soal tersebut?

Siswa $B$ : caranya, dengan memisalkan jarak rumah Rudi ke sekolah, yaitu jika jaraknya $80 \mathrm{~km}$ dan $70 \mathrm{~km}$. Ternyata setelah dilakukan pengecekan yang cocok ketika jaraknya adalah $70 \mathrm{~km}$.

Peneliti : kenapa kamu memilih dan memisalkan jaraknya hany $80 \mathrm{~km}$ dan $70 \mathrm{~km}$ ?

Siswa $B$ : soalnya kalau dinalar gak mungkin bilangan-bilagannya yang 61 atau 72 , gitu mungkin Pak.

Penulis : bukankah jarak rumah Rudi ke sekolah memiliki jarak yang tetap? Gimana pendapat kamu?

Siswa $B$ : memang tetap, Pak.

Penulis : kalau jaraknya memang tepat, kenapa kamu dapat memisalkan bahwa jaraknya adalah $80 \mathrm{~km}$ dan $70 \mathrm{~km}$ ? 
Siswa $B$ : saya misalkan dengan jawaban yang mungkin, Pak. Jadi saya pake cara coba-coba.

Berdasarkan hasil wawancara tersebut menunjukkan bahwa siswa $B$ memiliki kemampuan berpikir kreatif pada kategori sedang, akan tetapi masih berada pada level 4 berdasarkan level metakognisinya. Menurut Murti (2011) hal ini terjadi dikarenakan bahwa metakognitif berkembang seiring usia dan dipengaruhi latihan. Sedangkan hasil penelitian yang dilakukan oleh Wulantina (2015) siswa dengan kemampuan sedang siswa berusaha menggali informasi, mengidentifikasi masalah yang ditanyakan dengan baik namun kurang konsisten dalam memilih informasi yang dibutuhkan dan informasi yang tidak dibutuhkan dalam penyelesaian masalah.

\section{Pada Soal Nomor 6:}

Sejumlah siswa mengikuti ujian seleksi OSN tahun 2016 tingkat kota, ternyata didapatkan data bahwa sebanyak 64 siswa yang lulus adalah wanita, $\frac{3}{5}$ peserta yang lulus adalah laki-laki, Sedangkan jumlah peserta laki-laki lulus adalah 4 kali lebih banyak dari pada jumlah peserta laki-laki yang tidak lulus, serta jumlah peserta yang tidak lulus adalah 40 siswa. Berapa persenkah jumlah peserta wanita yang mengikuti ujian seleksi tersebut?

\section{Alternatif penyelesaian siswa $C$}

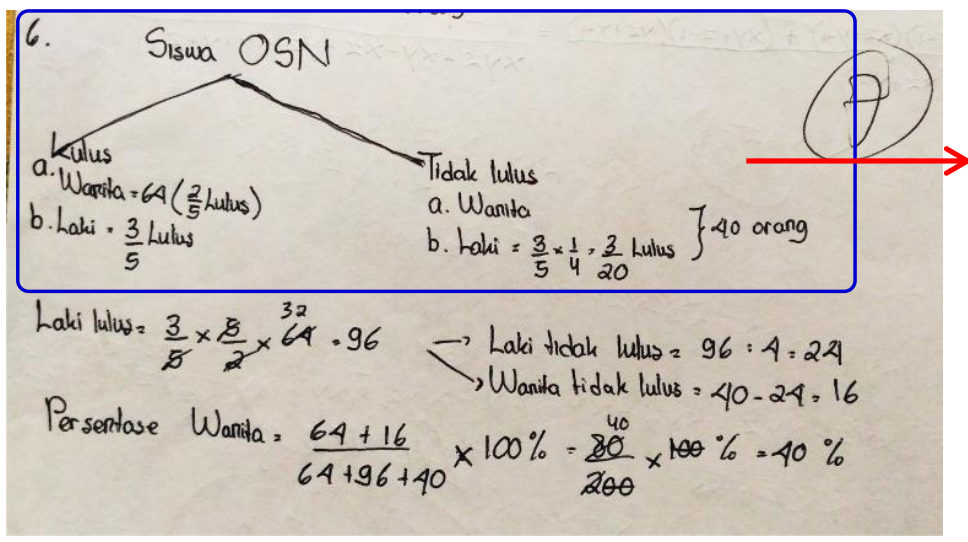

Strategi yang digunakan oleh siswa $C$ cukup unik dan berbeda dengan strategi dari siswa yang lain, yaitu untuk menemukan prosesntasi jumlah peserta wanita yang mengikuti ujian seleksi dengan membagi dua bagian untuk siswa yang lulus dan tidak lulus.

Kemudian siswa $C$ menggunakan strategi yang dipilih untuk memperoleh jawaban, akan tetapi siswa $C$ kurang cermat dalam memahami soal nomor 6 . Oleh karena alternatif penyelesaiannya dari siswa $C$ cukup unik tapi kurang cermat, maka penulis melakukan wawancara khusus kepada siswa $C$, bagaimana sebenarnya dia menemukan strategi dan menggunakannya. Berikut hasil wawancaranya.

Peneliti : apakah kamu pernah tahu soal seperti ini?

Siswa $C$ : saya pernah lihat soal sini, tapi lupa caranya.

Peneliti : bagaimana strategi yang kamu pilih untuk mendapatkan jawaban dari soal tersebut?

Siswa $B$ : caranya, membagi menjadi dua bagian untuk siswa yang lulus dan siswa yang tidak lulus 
Peneliti : apakah yang kamu pahami tentang pernyataan “ $\frac{3}{5}$ peserta yang lulus adalah laki-laki" dan "sedangkan jumlah peserta laki-laki lulus adalah 4 kali lebih banyak dari pada jumlah peserta laki-laki yang tidak lulus"

Siswa $C$ : he he he... saya kurang teliti, Pak.

Berdasarkan hasil wawancara tersebut menunjukkan bahwa siswa $C$ memiliki kemampuan berpikir kreatif pada kategori cukup dan berada pada level 2 berdasarkan level metakognisinya. Hal ini terjadi dikarenakan siswa yang termasuk kategori rendah belum memahami soal yang dihadapi dan belum pernah mengerjakan soal-soal olimpiade secara kontinu, sehingga pemahaman terhadap soal seringkali kurang tepat. Hal ini sesuai dengan penelitian Defitriani (2014) menyimpulkan bahwa siswa tidak kreatif berusaha untuk memahami masalah yang dihadapainya, namun pemahamannya kurang tepat. Adapun penelitian yang dilakukan Siswono (2008) yang menyatakan bahwa siswa tidak kreatif yakin dengan ide yang mereka punya, tapi dalam menyelesaikan soal mereka melakukan kesalahan. Hal ini sesuai dengan apa yang dikatakan oleh Soekamto (Tohir, 2019) bahwa seseorang dapat melupakan informasi yang telah diperoleh karena ia gagal untuk merubah ingatan jangka pendek menjadi ingatan jangka panjang karena kurang adanya pengulangan atau karena dia tidak dapat mengelompokkan informasi yang diperolehnya.

Dengan demikian, berdasarkan hasil penelitian yang didapat oleh penulis, dijabarkan pata tabel 3 berikut tentang tingkat keterampilan berkreatif siswa berdasarkan rincian indikator.

Tabel 3 Tingkat Keterampilan Berpikir Kreatif Siswa

\begin{tabular}{|c|c|c|c|}
\hline \multirow{2}{*}{ No. } & \multirow{2}{*}{ Kategori } & \multicolumn{2}{|c|}{$\begin{array}{c}\text { Data Tingkat Keterampilan Berpikir } \\
\text { Kreatif }\end{array}$} \\
\hline & & Jumlah & Persentase (\%) \\
\hline 1 & $\begin{array}{l}\text { Tingkat } 0 \\
\text { (Tidak Kreatif) }\end{array}$ & 0 & 0 \\
\hline 2 & $\begin{array}{l}\text { Tingkat } 1 \\
\text { (Kurang } \\
\text { Kreatif) }\end{array}$ & 5 & 29,41 \\
\hline 3 & $\begin{array}{l}\text { Tingkat } 2 \\
\text { (Cukup Kreatif) }\end{array}$ & 7 & 41,18 \\
\hline 4 & $\begin{array}{l}\text { Tingkat } 3 \\
\text { (Kreatif) }\end{array}$ & 2 & 11,76 \\
\hline 5 & $\begin{array}{l}\text { Tingkat } 4 \\
\text { (Sangat } \\
\text { Kreatif) }\end{array}$ & 3 & 17,65 \\
\hline
\end{tabular}

Alifmatika: Jurnal Pendidikan dan Pembelajaran Matematika, Desember 2019, Vol. 1, No. 1 
Berdasarkan data yang disajikan pada Tabel 3 di atas, secara keseluruhan menunjukkan bahwa keterampilan berpikir kreatif siswa berada pada kategori kurang kreatif sebanyak 3 siswa, terdapat 7 siswa yang berada pada kategori cukup kreatif, terdapat 2 siswa yang berada pada kategori kreatif, sedangkan sebagian yang lain memiliki kategori sangat kreatif, yaitu terdapat 3 siswa. Hal ini sesuai dengan yang dikatakan oleh Guilford (Rahmawati, 2016) mengatakan bahwa kemampuan berpikir kreatif seseorang memiliki jenjang (bertingkat), sesuai dengan karya-karya yang dihasilkan dalam bidang yang bersangkutan. Adapun menurut pendapat dari Edward de Bonno (Gie, 2003) bahwa berpikir kreatif dapat dipelajari, aspek umum dari kognitif ini dapat diperkuat dengan pengajaran dan pelatihan. The Liang Gie (2003) juga menjelaskan bahwa kemampuan berpikir kreatif seseorang dapat ditingkatkan dengan memahami proses berpikir kreatifnya dan berbagai faktor yang mempengaruhi, serta melalui latihan yang tepat. Sedangkan berdasarkan hasil penelitian yang ditemukan oleh (Tohir et al., 2018) menunjukkan bahwa perlu adanya suatu tahapan khusus untuk membelajarkan kepada siswa tentang bagaimana cara menemukan ide awal ketika menghadapi soal olimpiade matematika dan bagaimana menyusun strategi yang tepat juga berdasarkan ide awal yang didapat. Oleh karena itu, perlu adanya pembinaan olimpiade matematika secara kontinu dan berkesinambungan antara siswa dengan para pembina, berlatih dengan mengerjakan berbagai bentuk soal olimpiade matematika terutama soal yang up to date, dan sering mengikuti kompetisi olimpiade matematika, baik tingkat kabupaten/kota, provinsi, nasional maupun internasional.

Sedangkan hasil penelitian berdasarkan level metakognitif siswa dapat dijelaskan pada tabel 4 sebagai berikut.

Tabel 4 Level Metakognisi Siswa

\begin{tabular}{|c|c|c|c|}
\hline \multirow{2}{*}{ No. } & \multirow{2}{*}{ Level } & \multicolumn{2}{|c|}{ Data Metakognisi Siswa } \\
\hline & & Jumlah & Persentase $(\%)$ \\
\hline 1 & $\begin{array}{c}\text { Level } 1 \\
\text { (Tacit Use) }\end{array}$ & 0 & 0 \\
\hline 2 & $\begin{array}{c}\text { Level } 2 \\
\text { (Aware Use) }\end{array}$ & 11 & 64,71 \\
\hline 3 & $\begin{array}{c}\text { Level } 3 \\
\text { (Strategic } \\
\text { Use) }\end{array}$ & 4 & 23,53 \\
\hline 4 & $\begin{array}{c}\text { Level } 4 \\
\text { (Reflective } \\
\text { Use) }\end{array}$ & 2 & 11,76 \\
\hline
\end{tabular}

Berdasarkan data yang disajikan pada Tabel 4 menunjukkan bahwa lebih sebagian besar siswa berada pada level 2 (aware use), yaitu sebanyak 11 siswa. Level 2 merupakan jenis berpikir yang menunjukkan seseorang menyadari "apa"

Alifmatika: Jurnal Pendidikan dan Pembelajaran Matematika, Desember 2019, Vol. 1, No. 1 
dan "kapan" dia melakukan sesuatu. Siswa menyadari segala sesuatu yang dilakukan dalam memecahkan masalah. Terdapat 4 siswa yang berada pada level 3 (strategic use). Level 3 merupakan jenis berpikir yang menunjukkan seseorang mengorganisasi pemikirannya dengan menyadari strategi-strategi khusus yang meningkatkan ketepatan berpikir. Sebagian 2 siswa lain berada pada level 4 (reflective use), yang mana level 4 merupakan jenis berpikir yang menunjukkan seseorang melakukan refleksi tentang pemikirannya dengan mempertimbangkan perolehan dan bagaiman memperbaikinya. Hasil ini menunjukkan bahwa terdapat faktor-faktor yang dapat mempengaruhi level metakognisi siswa, yaitu faktor internal dan eksternal. Adapun berdasarkan hasil penelitian yang didapat oleh (Alkadrie, Mirza, \& Hamdani, 2015) menunjukkan bahwa faktor eksternal merupakan faktor dominan yang mempengaruhi level metakognisi siswa. Sedangkan menurut Anggo (Kholid M. N.; Lestari, 2019) mengatakan bahwa Metakognisi bermanfaat dalam membangun kesadaran seseorang akan pengetahuannya, serta pengaturan berpikir selama berlangsungnya proses pemecahan masalah. Oleh karena itu, semikin sering mengasah kemampuan seseorang, maka akan semakin tinggi kemampuan metakognisi orang tersebut, sehingga akan semakin tinggi juga kemampuan dan keteramppilan seseorang dalam memecahkan masalah yang dihadapi.

\section{KESIMPULAN DAN SARAN}

Berdasarkan hasil penelitian dan pembahasan yang telah diuraikan sebelumnya, dapat disimpulkan bahwa: (1) Keterampilan berpikir kreatif siswa terdapat pada pada kategori cukup kreatif. Hal ini disebabkan karena berdasarjan uraian karakteristik keterampilan berpikir kreatif matematika pada masingmasing predikat diperoleh bahwa secara umum siswa cukup mampu dalam memenuhi sebagian indikator berpikir kreatif. Berdasarkan hasil analisis, faktorfaktor yang mempengaruhi kemampuan berpikir kreatif siswa yang mengikuti pembinaan olimpiade matematika antara lain kecermatan dalam menyelesaikan soal-soal test, kecenderungan siswa dalam mengandalkan hafalan, tiruan dan motivasi. Sedangkan untuk mengembangkan keterampilan berpikir kreatif matematika siswa antara lain dapat ditempuh dengan meningkatkan motivasi dalam mengembangkan konsep-konsep yang telah didapat sebelumnya, mengerjakan soal-soal olimpiade secara kontinu, dan membaca dengan cermat soal-soal yang dihadapi sehingga kemampuan dalam mengidentifikasi dan menganalisis permasalahan akan lebih baik; dan (2) Ketika mengukur level metakognitif siswa akan lebih baik jika selalu dilakukan pada setiap waktu tertentu, karena level metakognitif seseorang selalu berkembang seiring usia dan dipengaruhi latihan-latihan yang rutin. Kematangan dan perkembangan biologis serta pembinaan olimpiade yang baik akan mampu mengembangkan kemampuan berpikir dan berperilaku. Cara seperti ini dapat mengembangkan kemampuan metakognitif siswa. Ketika kemampuan metakognitif siswa mulai berkembang, maka tingkat berpikir siswa tidak hanya selalu sampai pada level 2 (aware use) saja, akan tetapi bisa naik ke level yang lebih tinggi, yaitu leval 3 (strategic use), bahkan bisa naik ke level 4 (reflective use).

Alifmatika: Jurnal Pendidikan dan Pembelajaran Matematika, Desember 2019, Vol. 1, No. 1 
Bagi siswa hendaknya dapat menerapkan dengan baik ilmu yang telah didapat sebelumnya, sehingga dalam menghadapi berbagai tipe soal olimpiade matematika dapat dikerjakan dengan baik dan benar. Siswa harus aktif dalam setiap pembinaan olimpiade matematika dan tidak hanya terpusat pada konsep yang diajarkan guru namun juga harus mengembangkan konsep tersebut melalui studi literatur maupun latihan-latihan dalam bentuk soal yang lain, sehingga akan mengasah keterampilan berpikir kreatifnya. Diharapkan kepada tenaga pendidik atau para peneliti agar dapat melakukan research yang bervariasi kepada siswa yang mengikuti pembinaan olimpiade secara kontinu. Hal ini dimaksudkan agar keterampilan berpikir kreatif siswa dapat terlatih dan dikembangkan. Selain itu hendaknya pendidik atau para peneliti dapat menerapkan pembinaan yang dapat mengaktifkan dan mengotimalkan potensi siswa dengan didorong oleh berbagai pendekatan pembinaan.

\section{DAFTAR PUSTAKA}

Alkadrie, R. P., Mirza, A., \& Hamdani. (2015). Faktor-Faktor yang Mempengaruhi Level Metakognisi dalam Pemecahan Masalah Pertidaksamaan Kuadrat di SMA. Jurnal Pendidikan Dan Pembelajaran Untan.

As'ari, A. R., Tohir, M., Valentino, E., Imron, Z., \& Taufiq, I. (2017). Buku Guru Matematika (Revisi). Jakarta: Pusat Kurikulum dan Perbukuan, Balitbang, Kemendikbud.

Coutinho, S. A. (2007). The Relationship Between Goals, Metacognition, and Academic Success. Educate , 7(1), 39-47.

Defitriani, E. (2014). Profil Berpikir Kreatif Siswa Kelas Akselerasi dalam Memecahkan Masalah Matematika Terbuka. Jurnal Ilmiah Matematika Dan Pendidikan Matematika, 6(2), 65-76.

Gartmann, S., \& Freiberg, M. (1995). Metacognition and Mathematical Problem Solving: Helping Students to Ask the Right Questions. Metacognition and Mathematical Problem Solving: Helping Students to Ask the Right Questions, $6(1)$.

Gie, T. L. (2003). Tehnik Berpikir Kreatif. Yogyakarta: Sabda Persada Yogyakarta.

Kholid M. N.; Lestari, N. P. (2019). Metakognitif Siswa dalam Menyelesaikan Soal Matematika Berbasis PISA pada Konten Change and Relationship. Universitas Muhamadiyah Surakarta, (1), 121.

Munandar, U. (2012). Pengembangan Kreativitas Anak Berbakat. Jakarta: Rineka Cipta.

Murti, H. A. S. (2011). Metakognisis dan Theory of Mind (ToM). Jurnal Psikologi Pitutur, 1(2), 53-64. https://doi.org/10.1080/01426391003746549

P21. (2014). Learning for the 21st Century: A Report and MILE Guide for. Retrieved from http://www.21stcenturyskills.org 
Rahmawati, N. T. (2016). Kemampuan Berpikir Kreatif Matematik Siswa pada Pembelajaran SSCS dengan Tinjauan Metakognisi. PRISMA, Prosiding Seminar Nasional Matematika, (2), 150-160.

Romli, M. (2012). Strategi Membangun Metakognisi Siswa SMS dalam Pemecahan Masalah Matematika. Aksioma: Jurnal Matematika Dan Pendidikan Matematika UPGRIS Semarang, 1(2).

Sari, A. P., Ikhsan, M., \& Saminan, S. (2017). Proses Berpikir Kreatif Siswa dalam Memecahkan Masalah Matematika Berdasarkan Model Wallas. Beta Jurnal Tadris Matematika, 10(1), 18-32. https://doi.org/10.20414/betajtm.v10i1.102

Siswono. (2008). Model Pembelajaran Matematika Berbasis Pengajuan dan Pemecahan Masalah untuk Meningkatkan Kemampuan Berpikir Kreatif. Surabaya: Unesa University Press.

Sophianingtyas, F., \& Sugiarto, B. (2013). Identifikasi Level Metakognitif Siswa dalam Memecahkan Masalah Materi Perhitungan Kimia. UNESA Journal of Chemical Education, 2(1), 21-27.

Sugiyono. (2017). Metode Penelitian Kuantitatif, Kualitatif dan R\&D. Bandung: Alfabeta.

Syaiful. (2011). Metakognisi Siswa dalam Pembelajaran Matematika Realistik di Sekolah Menengah Pertama. Jurnal Edumatica, 1(2), 1-13.

Tohir, M., Abidin, Z., Dafik, D., \& Hobri, H. (2018). Students Creative Thinking Skills in Solving Two Dimensional Arithmetic Series Through Research-Based Learning. Journal of Physics: Conference Series, 1008(1), 012072. https://doi.org/10.1088/1742-6596/1008/1/012072

Tohir, Mohammad. (2017). Pengembangan Bahan Ajar Olimpiade Matematika Berdasarkan Model Pemecahan Masalah untuk Meningkatkan Kemampuan Penalaran Matematis Siswa. In Tesis. Magister Pendidikan Matematika Universitas Jember. https://doi.org/10.13140/RG.2.2.31121.79200

Tohir, Mohammad. (2019). Peningkatan Kompetensi Guru Pembina Olimpiade Matematika Siswa Sekolah Menengah Pertama Kabupaten Madiun. AsSidanah: Jurnal Pengabdian Masyarakat, 1(2), 199-226. https://doi.org/10.35316/assidanah.v1i2.587

Tohir, Mohammad, Susanto, Hobri, Suharto, \& Dafik. (2018). Students' Creative Thinking Skills in Solving Mathematics Olympiad Problems Based on ProblemSolving Polya and Krulik-Rudnick Model. Advanced Science Letters, 24(11), 8361-8364. https://doi.org/10.1166/asl.2018.12563

Wulantina, E. . K. T. A. . R. (2015). Proses Berpikir Kreatif Siswa dalam Pemecahan Masalah Matematika Ditinjau dari Kemampuan Matematika pada Siswa Kelas X MIA SMAN 6 Surakarta. Jurnal Elektronik Pembelajaran Matematika, 3(6), 671-682. 